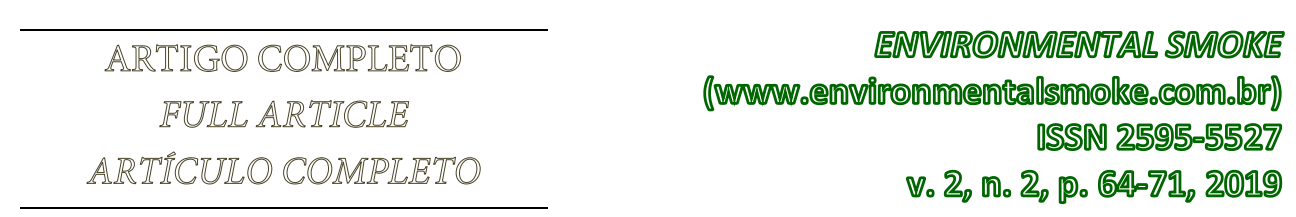

\title{
PHYSIOTHERAPEUTIC INTERVENTION IN PATIENTS AFFECTED BY THE SYNDROME OF SPOAN: AN EXPERIENCE REPORT
}

\author{
Neila Alves de QUEIROZ1; Rosemary Araújo MONTEIRO² ${ }^{\mathbf{1}}$ Marylia Paula BEZERRA ${ }^{\mathbf{3}}$; \\ Martin Lindsey CHRISTOFFERSEN ${ }^{4}$
}

\author{
${ }^{1}$ Graduação em Fisioterapia/Universidade Federal do Rio Grande do Norte (UFRN), Brasil. E-mail: \\ neilaaq@hotmail.com \\ ${ }^{2}$ Graduação em Fisioterapia/Universidade Federal da Paraíba (UFPB), Brasil; Mestra em Desenvolvimento e \\ Meio Ambiente (PRODEMA/UFPB), Brasil; Professora Adjunta I/UFRN, Brasil. E-mail: \\ rosemarymonteiro1@gmail.com \\ ${ }^{3}$ Graduação em Fisioterapia/Universidade Potiguar (UnP), Brasil. E-mail: marylia_paula@hotmail.com \\ ${ }^{4}$ Bacharel e Licenciado em Ciências Biológicas/Universidade de São Paulo (USP), Brasil; Doutor em Ciências \\ Biológicas/USP; Professor Titular/UFPB, Brasil.E-mail: mlchrist@dse.ufpb.br
}

\begin{abstract}
The SPOAN syndrome is a neurodegenerative disease of autosomal recessive inheritance that causes atrophy of muscles of the upper and lower limbs of the affected individuals. The disease had its initial characterization carried out in individuals originating in the upper western part of the city of Serrinha dos Pintos, State of Rio Grande do Norte, by researchers from the Center for Human Genome Studies and Hospital das Clínicas of the University of São Paulo in the year 2005. Its clinical characteristics include: congenital and atrophic optic atrophy Progressive spastic paraplegia, with early onset of life, axonal neuropathy, with clinical onset after the first decade of life, startle response with unexpected sounds, dysarthria, spinal and foot deformities, and extrapyramidal signs. The present text aims to report the cases of patients with SPOAN under the physiotherapeutic assistance of the Expanded Nucleus of Family Health (NASF) in the city of Serrinha dos Pintos-RN. Experience report: This is an experience report on the care of patients with SPOAN syndrome assisted by the municipality's NASF. In the municipality there were 14 patients with SPOAN, but only 4 (28.5\%) of these patients attended the physiotherapeutic care. The treatment lasted an average of 40-50 minutes, with moderate resting pauses between sessions. They consisted of: passive joint mobilization exercises, scapular and pelvic girdle dissociation exercises, intra-articular mobilization exercises, stretching, muscle strengthening, respiratory exercises, myofascial release, Kabat methods, Bobath and Pilates, electrotherapy, and auriculotherapy. Final considerations: Physiotherapic care given to patients with SPOAN syndrome is considered to be extremely important for the preservation of functionality of these patients, since there is a satisfactory clinical evolution, with improvement of muscular strength and flexibility, range of joint movement and respiratory capacity. Therefore, future studies regarding the diagnosis and prognosis of SPOAN are necessary, since early appropriate therapeutic intervention allows the best functional outcome.
\end{abstract}


Keywords: SPOAN syndrome; Physiotherapy; Paraplegia.

\section{ATUAÇÃO FISIOTERAPÊUTICA EM PACIENTES COM SÍNDROME DE SPOAN: UM RELATO DE EXPERIÊNCIA}

Resumo. A síndrome de SPOAN (do acrônimo em inglês Spastic Paraplegia, Optic atrophy, and Neuropathy) é uma doença neurodegenerativa de herança autossômica recessiva que causa atrofia de músculos dos membros superiores e inferiores dos indivíduos afetados. A doença teve sua caracterização inicial realizada em indivíduos originários de Serrinha dos Pintos localizada no alto oeste potiguar, por pesquisadores do Centro de Estudos do Genoma Humano e do Hospital das Clínicas da USP no ano de 2005. Suas características clínicas incluem: atrofia óptica congênita e não progressiva; paraplegia espástica progressiva, com início precoce de vida; neuropatia axonal, com início clínico após a primeira década de vida; resposta de sobressalto com sons inesperados; disartria; deformidades da coluna e dos pés e sinais extrapiramidais. O presente texto tem como objetivo relatar os casos de pacientes portadores de SPOAN sob a assistência fisioterapêutica do Núcleo Ampliado de Saúde da Família (NASF) no município de Serrinha dos Pintos-RN. Trata-se de um relato de experiência na assistência de casos de pacientes com Síndrome de SPOAN assistidos pelo NASF do município. No município havia 14 portadores de SPOAN, mas apenas $4(28,5 \%)$ destes frequentavam o atendimento fisioterapêutico. O atendimento durava em média de 40-50 minutos, com moderadas pausas para descanso entre as condutas e consistia em: exercícios de mobilização articular passiva global, exercícios de dissociação de cinturas escapular e pélvica, exercícios de mobilização intraarticular, alongamentos, fortalecimento muscular, exercícios respiratórios, liberação miofascial, métodos Kabat, Bobath e Pilates, eletroterapia e auriculoterapia. A assistência fisioterapêutica prestada a pacientes com Síndrome de SPOAN é notada como de extrema importância para a conservação da funcionalidade destes pacientes, pois notadamente há evolução clínica satisfatória, com melhora da força e flexibilidade muscular, amplitude de movimento articular e capacidade respiratória. Dessa forma, são necessários estudos futuros em relação do diagnóstico e prognóstico da SPOAN, pois a intervenção terapêutica adequada precoce possibilita o melhor desfecho funcional.

Palavras-chave: Síndrome de SPOAN; Fisioterapia; Paraplegia.

\section{ACTUACIÓN FISIOTERAPÉUTICA EN PACIENTES CON SÍNDROME DE SPOAN: UN RELATO DE EXPERIENCIA}

Resumen: El síndrome de SPOAN (del acrónimo en inglés Spastic Paraplegia, Optic atrophy, and Neuropathy) es una enfermedad neurodegenerativa de herencia autosómica recesiva que causa atrofia de músculos de los miembros superiores e inferiores de los individuos afectados. La enfermedad tuvo su caracterización inicial realizada en individuos originarios de Serrinha de los Pintos ubicada en el alto oeste potiguar, por investigadores del Centro de Estudios del Genoma Humano y del Hospital de 
las Clínicas de la USP en el año 2005. Sus características clínicas incluyen: atrofia óptica congénita y, que se ha convertido en una de las principales causas de muerte en los últimos años, y que se ha convertido en una de las principales causas de muerte. El presente texto tiene como objetivo relatar los casos de pacientes portadores de SPOAN bajo la asistencia fisioterapéutica del Núcleo Ampliado de Salud de la Familia (NASF) en el municipio de Serrinha de los Pintos, State of Rio Grande do Norte. Relato de experiencia: Se trata de un relato de experiencia en la asistencia de casos de pacientes con Síndrome de SPOAN asistidos por el NASF del municipio. En el municipio había 14 portadores de SPOAN, pero sólo $4(28,5 \%)$ de estos frecuentaban la atención fisioterapéutica. La atención duraba en promedio de 40-50 minutos, con moderadas pausas para descanso entre las conductas y consistía en: ejercicios de movilización articular pasiva global, ejercicios de disociación de cinturas escapular y pélvica, ejercicios de movilización intraarticular, estiramientos, fortalecimiento muscular, ejercicios respiratorios, liberación miofascial, métodos Kabat, Bobath y Pilates, electroterapia y auriculoterapia. En el caso de los pacientes con Síndrome de SPOAN se observa que es de extrema importancia para la conservación de la funcionalidad de estos pacientes, pues notablemente hay evolución clínica satisfactoria, con mejora de la fuerza y flexibilidad muscular, amplitud de movimiento articular y capacidad respiratoria. De esta forma, son necesarios estudios futuros en relación al diagnóstico y pronóstico de la SPOAN, pues la intervención terapéutica adecuada precoz posibilita el mejor desenlace funcional.

Palabras clave: Síndrome de SPOAN; Fisioterapia; Paraplejia.

\section{INTRODUCTION}

The SPOAN syndrome (acronym for Spastic Paraplegia, Optic atrophy, and Neuropathy) is a neurodegenerative disease of autosomal recessive inheritance that causes atrophy of muscles of the upper and lower limbs of the affected individuals (MACEDO-SOUZA, 2005; SOUZA, 2008). The disease had its initial characterization carried out in individuals originating in the upper western part of the city of Serrinha dos Pintos, State of Rio Grande do Norte, by researchers from the Center for Human Genome Studies and Hospital das Clínicas of the University of São Paulo in the year 2005 (PIVETTA, 2005).

Spastic Paraplegia, Optic atrophy, and Neuropathy (SPOAN syndrome) is a complex type of hereditary spastic paraplegia. It affects more than one path or region of the central nervous system in patieonts bearing this syndrome. In general, the signals that accompany a complex hereditary spastic paraplegia are: spasticity, debilitation, hyper-reflexiveness, and the Babinski signal, that characterize typical cases of hereditary spastic paraplegia. To these syntoms may be added neurological or non-neurological deficits, including motor and 
peripheral neuropathy, optic atrophy, mental retardation, insanity, among others (VIEIRA, 2007; OLIVEIRA; VASCONCELOS; FIXINA, 2013).

The clinical characteristics of the SPOAN syndrome include: congenital and atrophic optic atrophy, progressive spastic paraplegia, with early onset of life, axonal neuropathy, with clinical onset after the first decade of life, startle response with unexpected sounds, dysarthria, spinal and foot deformities, and extrapyramidal signs (AMORIM et al., 2014; GRACIANI et al., 2010).

The first synthoms of the illness occur during the first months of life, relating to the atrophy of the optic nerve. The onset of a fixed nystagmus, in which the child sees only about $10 \%$ of what a normal child would see (VIEIRA, 2007; OSADA; COSTA, 2011). The signs of motor limits appear usually before the first year of life. Intense incapacitation begins with the lower limbs in the form of progressive spasmic paraplegia, which leads the patient to develop a kind march on the tip of the feet up to about the age of 10 years. After that even this marching locomotion is entirely lost. Until the age of around 20 years locomotion becomes possible only with walking devides. The commitment of the upper limbs begins a about 20 years old (MACEDO-SOUZA, 2005; PIVETTA, 2005; VIEIRA, 2007). In SPOAN syndrome, there occurs the combined commitment of legs and arms that caracterizes a serious case of precocious motor-sensitive axonal polineuropathy (AMORIM et al., 2014; GRACIANI et al., 2010; OLIVEIRA; VASCONCELOS; FIXINA, 2013).

Speech is also affected in patients commited with this syndrome. The muscles responsible for talking loose their strength. Patietns above 20 years of age frequently are affected by dysarthria associated with aphony. Cognitive deficiencies were not noted. Yet, due to their low visual capacity, most children abandon schooll during the first years (MACEDO-SOUZA, 2005; OSADA; COSTA, 2011; VIEIRA, 2007).

It has been estimated that one in every 250 inhabitants de Serrinha dos Pintos, where $32,5 \%$ of marriages occur between biologically related individuals, is affected by the SPOAN syndrome (SANTOS et al., 2010; SANTOS et al., 2014). Genetically the SPAN syndrome is associated with chromossome "11q13", but the gene responsible for the illness remains unknown (AMORIM et al., 2014; MACEDO-SOUZA, 2005; PIVETTA, 2005).

The joint clinical symptoms we have observed in patients commited with the SPOAN syndrome in Serrinha dos Pintos has never been described before in the literature (MACEDOSOUZA, 2005; VIEIRA, 2007). The illness is probably little known among health professionals, particularly among physiotherapists, due to the scarce scientific literature associating SPOAN with physiotherapeutic practice. No known cures are known for this 
illness. Only physiotherapy and drugs that delay the loss of muscle function in the body are indicated (OSADA; COSTA, 2011).

The present text aims to report cases of patients with SPOAN under the physiotherapeutic assistance of the Expanded Nucleus of Family Health (NASF) in the city of Serrinha dos Pintos, State of Rio Grande do Norte.

\section{EXPERIENCE REPORT}

This is an experience report on the care of patients with SPOAN syndrome assisted in the period from June 2017 to June 2018 by the municipality's NASF. The analyzed data were recorded in attendance medical sheets in accordance to a Resolution of the Federal Council of Physiotherapy and Occupational Therapy (BRASIL, 1987). Calls on patients were once a week by physiotherapists integrating NASF.

In the municipality there were 14 patients with SPOAN, but only $4(28.5 \%)$ of these patients attended the physiotherapeutic care provided by NASF. The remaining patients $(71,4 \%)$ were accompanied by means of home visits. Patients were forwarded to NASF by the Family Health Unit. To begin with a physiotherapeutic evaluation and an analysis of medical exams brought by the patients were conducted by the professional, when necessary. The establishment of a personal physiotherapeutic conduct depended on the state of the remaining body functions of each patient. In other words, the establishement of a subsequent physiotherapeutic protocol depended on the limitations, potentialities and deficits detected during the initial evaluation. This conduct determined the following assistance criterium for each patient thereafter.

All procedures were conducted in accordance with the daily necessities of each patient and in response to the therapeutic objectives of each session. The treatment lasted an average of 40-50 minutes, with moderate resting pauses between sessions. They consisted of: passive joint mobilization exercises, scapular and pelvic girdle dissociation exercises (activelyassisted or passive), intra-articular mobilization exercises, respiratory exercises, stretching, muscle strengthening, respiratory exercises, myofascial release, manual lymphatic drainage, sensory stimulation (ROOD), electrotherapy, and auriculotherapy.

\section{FINAL CONSIDERATIONS}

Physiotherapic care given to patients with SPOAN syndrome is considered to be extremely important for the preservation of functionality of these patients, since there is a satisfactory clinical evolution, with improvement of muscular strength and flexibility, range of joint 
movement and respiratory capacity. All assisted patients arrived at the service already presenting loss of the capacity for marching.

Physiotherapeutic stimulation promotes the maintainance of muscular force and flexibility, amplitude of articular movement and respiratory capacity. This prevents deformities and muscular-tendon retractions, as well as facilitating more functional body postures. Particularly important were the adaptation to the use of auxiliary locomotor therapeutic devices (ortheses), which contributed to the fulfillment of daily life activities.

It is noteworthy that assiduousness in physiotherapeutic treatment maitains and reduces the dependency of devices for daily activities by patients with SPOAN. This fact is reflected in a reduction of intervention by the caregiver, and a higher functional independence and life quality for these patients. It was also observed that in patients that did not perform the recommended daily exercises, or that gave up attending physiotherapeutic treatment, there occurred a decline in their overall body functions.

This account clarifies the complexity of aspects related to the physiotherapeutic assistance for patients with SPOAN. The physiotherapist professional shares responsibilities as a promotor and educator in the provision of care among patients and their kin and caregivers. Physiotherapy, as a science that studies, prevents and treats kinetic-functional disturbances, becomes indispensable for the assistance of these patients. Although the prognosis of this syndrome is not cheerful, the physiotherapist, aided with the abilities and competencies of a multiprofissional team, becomes an agent for developing mechanisms and strategies that are beneficial for the general life quality of these patients.

Presumably because SPOAN represents a rare condition, few references were found in the literature that deal with the treatment or physiotherapeutic conduct for the respective syndrome. Uncertainties regarding the nuances involved in this syndrome and the lack of specific information represent a challenge for the field of physiotherapy and the dealing with this condition in the working routine of the physiotherapist. The professional practice of the physiotherapist should be centered on an incessant techno-scientific search into this little known and explored domain. Future studies are necessary into the diagnostics, treatment and prognosis of SPOAN. All we know at present is that an adequate precocious therapeutic intervention permits a better functional outcome for the patient commited to the SPOAN syndrome.

A meticulous clinical eye is needed in the search for better treatments and better assistance for these patients, as well as a more humane and cozy outlook, respecting the autonomy of each patient. Furthermore, the search for this posture should be stimulated in the 
academic universe of the physiotherapist and other health professionals, with the objective of promoting further knowledge, experience and preparation for the future clinical attendance of patients with SPOAN.

\section{REFERENCES}

AMORIM, S.; HEISE, C.O.; SANTOS, S.; MACEDO-SOUZA, L.I.; ZATZ, M.; KOK, F. Nerve conduction studies in Spastic Paraplegia, Optic Atrophy, and Neuropathy (SPOAN) Syndrome. Muscle Nerve, v. 49, n. 1, p. 131-133, 2014.

BRASIL. Conselho Federal de Fisioterapia e Terapia Ocupacional. Resolução no 80, de 9 de maio de 1987. Diário Oficial da União nº 93 - de 21/05/87, Seção I, Págs. 7609. Baixa Atos Complementares à Resolução COFFITO-8, relativa ao exercício profissional do FISIOTERAPEUTA, e à Resolução COFFITO-37, relativa ao registro de empresas nos Conselhos Regionais de Fisioterapia e Terapia Ocupacional, e dá outras providências. Disponível em: http://www.crefito2.gov.br/legislacao/resolucoes-coffito/resolucao-80--de-09de-maio-de-1987--70.html. Acesso em: 24 abr. 2019.

GRACIANI, Z.; SANTOS, S; MACEDO-SOUZA, L.I.; MONTEIRO, C.B.M.; VERAS, M.I.; AMORIM, S.; ZATZ, M.; KOK, F. Motor and functional evaluation of patients with spastic paraplegia, optic atrophy, and neuropathy (SPOAN). Arquivos de Neuro-Psiquiatria, v. 68, n. 1 p. $3-6,2010$.

MACEDO-SOUZA, L.I.; KOK, F.; SANTOS, S.; AMORIM, S.C.; STARLING, A.; NISHIMURA, A.; LEZIROVITZ, K.; LINO, A.M.M.; ZATZ, M. Spastic Paraplegia, Optic Atrophy, and Neuropathy is linked to chromosome 11q13. Annals of Neurology, v. 57, n. 5, p. 730-737, 2005.

OLIVEIRA, L.C.; VASCONCELOS, R.B.; FIXINA, E.B. Síndrome SPOAN: uma questão de consanguinidade e de conquista de direitos. Revista de Enfermagem UFPE on line, Recife, v. 7, p-1001-1007, 2013.

OSADA, N.M.; COSTA, M.C. The construction of a genetic disease by molecular biology: actors, gender and, biomedicalization. Anais do IV Simpósio Nacional de Tecnologia e Sociedade. Curitiba, 2011. Disponível em: http://www.esocite.org.br/eventos/tecsoc2011/cdanais/arquivos/pdfs/artigos/gt021-aconstrucao.pdf. Acesso em: 19 mai. 2019. 
PIVETTA, M. Spoan: uma nova doença. Revista Pesquisa FAPESP, São Paulo, n. 113, jul. 2005. Disponível em: https://revistapesquisa.fapesp.br/2005/07/01/spoan-uma-nova-doenca/. Acesso em: 18 mai. 2019.

SANTOS, S.; KOK, F.; WELLER, M.; PAIVA, F.R.L.; OTTO, P.A. Inbreeding levels in Northeast Brazil: Strategies for the prospecting of new genetic disorders. Genetics and Molecular Biology, v. 33 n. 2, p. 220-223, 2010.

SANTOS, S.; PEQUENO, A.A.S.; PESSOA, A.; GALVÃO, C.R.C.; MEDEIROS, J.L.A.; MATHIAS, W.; KOK, F. Increased prevalence of inherited neuromuscular disorders due to endogamy in Northeast Brazil: the need of community genetics services. Journal of Community Genetics, v. 5, n. 3 p. 199-203, 2014.

SOUZA, L.I.M. Investigação genética de duas novas doenças neurodegenerativas: síndrome Spoan (Spastic Paraglegia with Optic Atrophy and Neuropathy) e SPG34. 79 f. Tese (Doutorado em Biologia/Genética)-Universidade de São Paulo, São Paulo, 2008.

VIEIRA, F.S.; AILY, S.M. Análise funcional de pacientes com SPOAN: paraplegia espástica com atrofia óptica e neuropatia. 54 f. Tese (Especialização em Intervenção Fisioterapêutica em Doenças Neuromusculares)-Universidade Federal de São Paulo, São Paulo, 2007. 